\title{
Understanding Paleoclimate and Human Evolution Through the Hominin Sites and Paleolakes Drilling Project
}

\author{
by Andrew Cohen, Ramon Arrowsmith, Anna K. Behrensmeyer, Christopher Campisano, \\ Craig Feibel, Shimeles Fisseha, Roy Johnson, Zelalem Kubsa Bedaso, \\ Charles Lockwoodt, Emma Mbua, Daniel Olago, Richard Potts, Kaye Reed, \\ Robin Renaut, Jean-Jacques Tiercelin, and Mohammed Umer
}

doi:10.2204/iodp.sd.8.10.2009

Understanding the evolution of humans and our close relatives is one of the enduring scientific issues of modern times. Since the time of Charles Darwin, scientists have speculated on how and when we evolved and what conditions drove this evolutionary story. The detective work required to address these questions is necessarily interdisciplinary, involving research in anthropology, archaeology, human genetics and genomics, and the earth sciences. In addition to the difficult tasks of finding, describing, and interpreting hominin fossils (the taxonomic tribe which includes Homo sapiens and our close fossil relatives from the last $6 \mathrm{Ma}$ ), much of modern geological research associated with paleoanthropology involves understanding the geochronologic and paleoenvironmental context of those fossils. When were they entombed in the sediments? What were the local and regional climatic conditions that early hominins experienced? How did local (watershed scale) and regional climate processes combine with regional tectonic boundary conditions to influence hominin food resources, foraging patterns, and demography? How and when did these conditions vary from humid to dry, or cool to warm? Can the history of those conditions (Vrba, 1988; Potts, 1996) be related to the evolution, diversification, stasis, or extinction of hominin species?

Most of the efforts to address these questions to date have centered on evidence from outcrops where the hominin fossils have been collected. Earth scientists have made great strides in understanding these contextual questions using fluvial, paleosol, and marginal lacustrine sediments associated with hominin fossils; however, this approach has its limitations. Outcrops, for example, cannot normally provide us with continuous, unweathered stratigraphic sections needed to address many questions relating events in hominin evolution and environmental change. The places where hominins actually lived (literally, above the water table) tend to have only discontinuous and relatively low resolution lithostratigraphic records of climate and other aspects of environmental change.

For these reasons the paleoanthropology community has turned to drill cores as a potential source of more highly

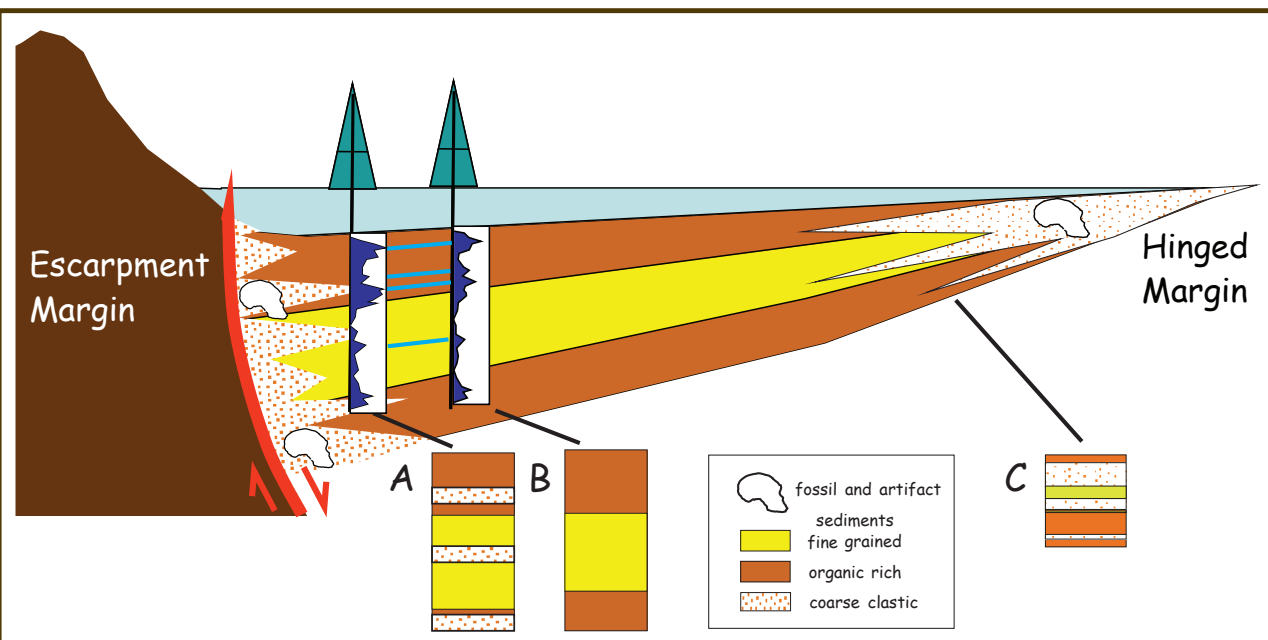

Figure 1. A conceptual model for drill site targeting in HSPDP (Hominin Sites and Paleolakes Drilling Project), using a half-graben rift basin depositional model. Note that a lake is shown in the diagrammatic cross section, although for the current phase of drilling we are targeting paleolake deposits where drilling from a barge can be avoided. The primary target (Drill Site B) would be far enough from the paleoshoreline to avoid most coarse clastic facies (pattern), with a relatively thick and highly resolved stratigraphic record. These types of offshore (fine-grained, organic rich) sediments (shown as yellow and brown solid colors) are most likely to yield the continuous paleoclimatic records useful for addressing current questions about hominin evolution/climate interactions. In contrast, a hinged margin site (C), even though potentially in close proximity to fossil and artifact localities, will yield a thinner and more discontinuous record, and one in which high stand lake deposits are over-represented. A more proximal target on the escarpment margin (A) will yield a dominantly coarse-grained stratigraphic record that is also less desirable for paleoclimate studies, although it may provide a useful secondary target for correlation into the hominin-bearing outcrops and/or records of tectonic uplift affecting the watershed. resolved paleoenvironmental information. This concept is not new. Almost thirty years ago, the U.S. National Science Foundation (NSF) sponsored a workshop to examine the potential of recovering long deepest and oldest of the modern African Rift Valley lakes, with a particular emphasis placed on how these records might inform our understanding of the environmental context of early hominin evolution (Lewin, 1981). In an influential paper, deMenocal (1995) demonstrated how northeastern African paleoclimate could be inferred from dust records encased in Deep Sea Drilling Project (DSDP) drill cores collected in the Gulf of Aden. This paper, as well as subsequent ones (deMenocal, sediment cores from the 
2004; Feakins et al., 2005) by the same research group, provided the first more-or-less continuous offshore record of Neogene climate for hominin evolution occurring nearby terrestrially, and also set out a research agenda for investigating the possible role of orbital forcing mechanisms on the timing of hominin evolution. The idea of drilling the African Great Lakes ultimately came to fruition in 2005 with the successful completion of the Lake Malawi Drilling Project (Scholz et al., 2006), which had important paleoclimate implications for hominin evolution and the expansion of anatomically modern humans out of Africa (Cohen et al., 2007).

Despite these successes, the role of scientific drilling in answering questions of importance to paleoanthropology is still hampered by the location of the drill core records currently available relative to where hominin fossils have actually been found. Both the Gulf of Aden and Lake Malawi lie at considerable distances from the important fossil hominin and artifact sites in East Africa. Additionally, in the case of the DSDP dust records, the signal itself integrates climate history over a vast area of northeastern Africa and Arabia. To address questions about local environmental conditions, a drilling effort was needed to specifically target these regions. The Hominin Sites and Paleolakes Drilling Project (HSPDP) grew out of this need.

During 17-21 November 2008, over sixty scientists from thirteen countries met in Addis Ababa, Ethiopia for a workshop entitled "Scientific Drilling for Human Origins: Exploring the Application of Drill Core Records to Understanding Hominin Evolution" to chart a new path forward in the application of drill core studies to understanding human evolution. This workshop followed up on an earlier (2005) meeting on the broader theme of "Paleoclimates and Human Evolution" (Cohen et al., 2006), as well as two years of exploratory research and site surveys at potential drill sites.

Major themes of the 2008 workshop were laid out in introductory talks by Andy Cohen and Rick Potts; they concerned general criteria guiding the HSPDP in its attempt to identify promising drilling sites and what we might learn from drilling that would be of interest to paleoanthropology. Ideal candidate sites for drilling would individually provide cores with very high temporal resolution and continuous records of basin scale environmental history and regional scale paleoclimate, would have the potential for excellent geochronologic control, and would be amenable to a wide range of analytical techniques (Fig. 1). To allow us to address questions of environment/hominin interactions on a local scale, ideal drilling locations would also be in close proximity and be geologically and chronologically related to important hominin fossil and artifact sites. In particular, lacustrine deposits can provide an extraordinary range of paleoecological, geochemical, and sedimentological records of past climate, and typically yield much higher resolution records than coeval fluvial deposits or paleosols. In the East African
Rift Valley, we have focused on relatively deep, paleolake deposits within the same depositional basins as important hominin fossil finds. Within rift half-graben lake basins, our search for ideal drilling targets has centered on what would have been the offshore portions of escarpment margins of half-grabens, where water depths would have been deepest and sediment accumulation rates highest over extended periods. Secondary objectives might include collecting cores from more proximal locations to the paleoshorelines, to tie in the paleoclimate records directly to fossil/archaeological sites via correlation and to collect records of tectonic activity and other processes within the watersheds. HSPDP has focused efforts on identifying several basins, spanning a range of "critical intervals" in hominin evolution. By comparing multiple lacustrine records, we have a realistic opportunity to address questions, for example, about the relationship between accurate local climatic records, possible orbital forcing mechanisms, or shorter (millennial scale) events with hominin evolutionary patterns such as adaptive radiations, species appearances, and species extinctions. With a highly detailed environmental record from each targeted basin, we can also compare the evolutionary responses to climate change in other biota to contrast possibly unique hominin responses to environmental variation (Potts, 1996). Interbasinal comparisons will also be critical for evaluating evolutionary hypotheses that invoke interactions between climate forcing and tectonic history in the rift (Sepulchre et al., 2006).

Precise measurements of climate change and rift dynamics may be associated with such things as the origin of Homo, major transitions in stone technology, rapid brain size increase, or the dispersal of $H$. sapiens; consequently, the goal is to substantially improve our ability to characterize the environmental factors that can be considered central to an understanding of human evolution.

Interregional and inter-temporal investigations will generate paleoenvironmental data for a series of repeated historical experiments, whose outcomes can be compared. As Potts suggested at the workshop, with drill core records in the basins where hominins have been recovered, we could evaluate the hypothesis that episodes of increased magnitude in environmental variability (e.g., recorded in paleo-precipitation proxies) correlate in time and space with hominin species diversification events and/or technological innovations. Through paleoclimate modeling approaches grounded in better data from core records, we will be better able to understand the dynamics that link climatic and evolutionary histories. Vegetation simulations using fully coupled General Circulation Models (GCMs) have already proven useful for understanding Quaternary climate changes relevant to the evolution of $H$. sapiens (Cowling et al., 2008).

To keep total project costs realistic given a goal of drilling multiple hominin basins, the HSPDP decided early on to pursue on-land drilling targets, accessible by a truck-mounted 
drill rig, rather than trying to return to extant lakes, where the logistics complexity and costs would be much greater. In 2007, HSPDP received funding from NSF to conduct site logistics and subsurface geophysical surveys at several promising localities (Fig. 2), which were the focus of much of the 2008 workshop discussion. All of these represented areas of long-standing geological and paleoanthropological research, where thick sequences of paleolake deposits occur in close proximity to important hominin or archaeological sites.

Chris Campisano described the scientific opportunities provided by the Northern Awash River Valley in the Afar region (Fig. 3), targeting the Middle Pliocene ( 3.8-2.9 Ma) Hadar Formation lake deposits. Nearby fluvio-lacustrine and paleosol deposits of this formation and the overlying Busidima Formation have yielded spectacular fossil and artifact discoveries, including the iconic Lucy, First Family, and Selaam (Dikika baby) fossils, all representing the early hominin species Australopithecus afarensis (Johanson and White, 1979; Johanson et al., 1982; Alemseged et al., 2005; Behrensmeyer, 2008; Campisano and Feibel, 2008; Wynn et al., 2008), as well as the oldest known stone tools (Semaw et al., 1997). All of the $A$. afarensis fossils (representing 90\% of the fossils of this taxon discovered to date) accumulated around the margins of a relatively deep rift lake, the deposits of which would be the target of this drilling project (Fig. 2).

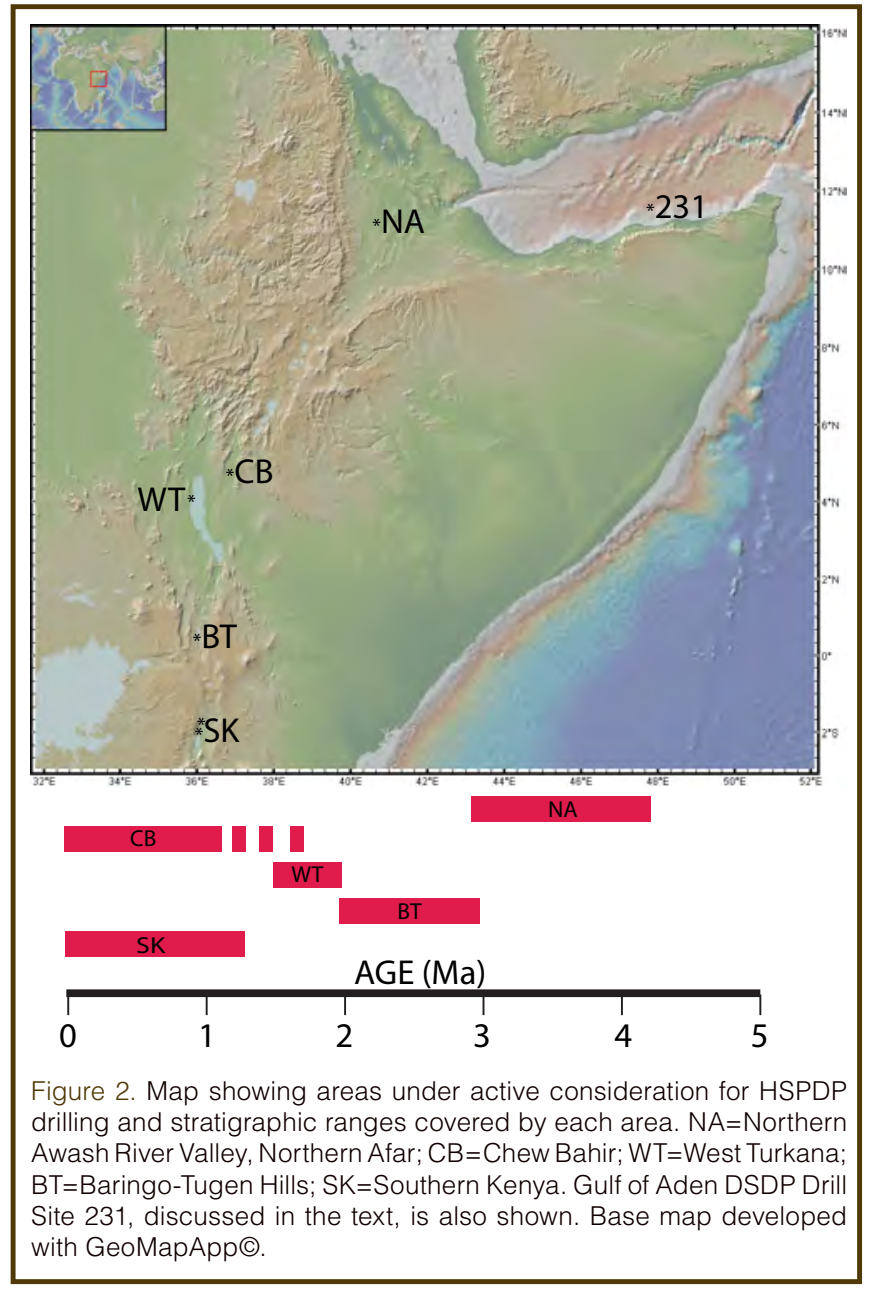

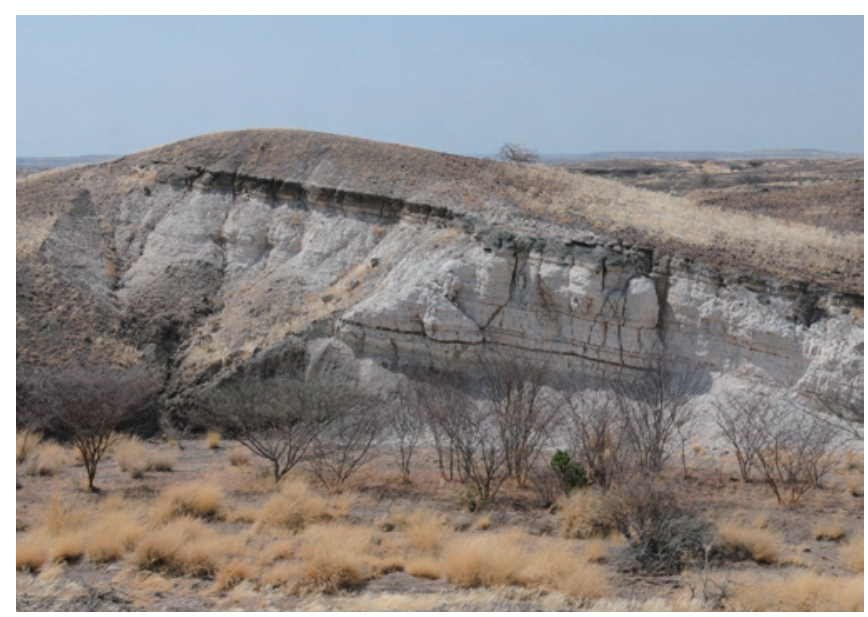

Figure 3. Outcrop photo of Middle Pliocene laminated diatomites from near the depocenter of a paleolake in the Northern Afar, one of the likely target locations and intervals for HSPDP drilling. Hill is about $8 \mathrm{~m}$ high.

Prior and ongoing geological research have focused drilling exploration efforts on the paleo-depocenter of a large Hadar basin lake, whose depositional cycles appear linked to global climate forcing (Campisano and Feibel, 2007; Dupont-Nivet, et al., 2008). A HSPDP team led by Roy Johnson conducted reflection seismic site surveys of potential drilling targets in this depocenter in 2008 with promising results.

Craig Feibel discussed potential onshore drilling targets on the west side of modern Lake Turkana in northern Kenya (Fig. 2). Plio-Pleistocene deposits rich in artifacts and fossils of hominins and other vertebrates (Harris et al., 1988; Feibel et al., 1989; Roche et al., 2004) accumulated in this region on the margins of large paleolakes (proto-Lake Turkana) (Lepre et al., 2007). A thick sequence of 2.0-1.5-Ma lake beds from one of these lacustrine phases would provide a continuous record of climate and environmental history during a particularly important interval of hominin evolution. Seminal events - such as evolution of several species of our own genus Homo, the first long-distance transport of stone tools, and the appearance of Acheulean (e.g., hand axe) types of tools, and the first expansion of hominins out of Africaall occur during this critical time interval. A HSPDP seismic reflection profile and logistics survey conducted in 2008, coupled with decades of prior stratigraphic research on local outcrops, provide clearly defined drilling targets for sampling the offshore paleolake deposits spanning this interval.

Two areas in the southern Kenya Rift Valley (Fig. 2) that have been evaluated for drilling logistics were also considered in detail. Kay Behrensmeyer explained the potential for drilling around the Pleistocene $(\sim 1.2-0.5 \mathrm{Ma})$ Olorgesailie lake basin. For many years, Olorgesailie has been recognized as one of the most important archaeological sites in the world for documenting Acheulean (and more recently, Middle Stone Age) technology, and the deposits also contain a rich vertebrate fossil record, including hominins (Isaac and Isaac, 1977; Potts and Deino, 1995; Potts et al., 2004). 
The fossils and stone tools occur on the margins of a Pleistocene lake, whose diatomaceous sediments would be one drilling target (Behrensmeyer et al., 2002; Owen et al., 2008). A terminal sump for the basin, the Koora Graben, forms another attractive target for obtaining an even higher resolution and more continuous paleoclimatic and paleohydrologic record for the basin. Robin Renaut discussed the potential for drilling nearby Lake Magadi, the second site of interest in the Rift Valley. This soda lake is well-known among sedimentologists and sedimentary geochemists (Eugster, 1980) and is also surrounded by a number of important Early and Middle Pleistocene archaeological and fossil hominin sites. The lake is currently the site of active trona production, making the playa surface readily accessible. It was drilled for mineral exploration purposes in the 1960s (unfortunately, the cores have been lost), and several studies have demonstrated the great potential of this basin for producing high resolution paleoclimate records (Taieb et al., 1991; Damnati and Taieb, 1995). Because Lake Magadi and Olorgesailie are in close proximity $(\sim 20 \mathrm{~km}$ apart) but occur in completely separate rift sub-basins (see Fig. 2) with no hydrologic connection, drill core records from both could allow paleoanthropologists to separate regional paleoclimatic effects on early hominin habitats from local watershed processes for the first time.

The workshop also provided opportunities to discuss other potential drilling targets. Alan Deino explained the potential for drilling Late Pliocene lake beds from the Tugen Hills region of the Lake Baringo Basin (central Kenya rift). The 3-2-Ma interval encompassed by these lake beds is also a period of important events in this time period, such as the first documented stone tools, the first fossils of Homo, and the evolution of several other hominin species. A sequence of well-dated, diatomaceous lake beds in the Tugen Hills area displays strong cyclicity interpreted as correlating to orbital (Milankovitch) time scales, making this an optimal site for testing ideas about linkages between hominin evolutionary events and climatic variability (Deino et al., 2006; Kingston et al., 2007). Giday WoldeGabriel discussed the potential of drilling in the Chew Bahir Basin in southern Ethiopia. This area sits on the interface between the Kenyan and Ethiopian rifts, regions whose biogeographic histories, despite their proximity, appear to be quite distinct. The area is also in close proximity to important Early Pleistocene fossil and archaeological sites (Suwa et al., 2007). The potential drilling target, a playa surface similar to Lake Magadi, will be the subject of preliminary field studies in late 2009. At the conclusion of the workshop, a call to the paleoanthropology and paleoclimate communities was issued by HSPDP for additional suggestions for sites that might be incorporated into future drilling proposals.

Much of the workshop was spent discussing analytical methods that might be used to study the cores collected. The wide range of techniques common to paleolimnological investigations (diatoms, ostracodes, pollen, stable isotopes, scanning XRF, sedimentology) were well-represented by researchers at the meeting. Additionally, leaders in exciting new methods in organic geochemistry, such as the $\mathrm{TEX}_{86}$, MBT, and leaf wax studies, raised the possibility of obtaining much improved quantitative reconstructions of temperature and precipitation for the basins under study. Making the most of all of these methods will require the continuous, unweathered samples afforded only by drilling. Geochronology was a major focus of discussion, with many participants considering how best to transfer our existing (outcrop-based) understanding of the stratigraphy and age models for each basin to core records. Because of the wide range of time scales under consideration, many different techniques will ultimately be used. It was evident from the lively discussion that HSPDP could be a proving ground for new dating and correlation methods and the extension in time of existing ones. Breakout groups considered how coordination between research groups might be achieved between the different drilling areas to obtain intersite comparability. This ultimately will be critical for synthesizing results and examining those patterns in the environmental history-hominin evolution relationship that transcend individual locations or time intervals. The application of appropriate statistical techniques to infer trends and periodicities (Trauth et al., 2009) will be essential for the success of HSPDP, as will a vigorous modeling component to provide explanatory theory for understanding any potential climate-hominin evolution linkages that we uncover.

A drilling project focusing on human evolution in Africa offers unprecedented educational opportunities for communities near the drill sites, for educators, and for museums. The number of sites that might be drilled will provide welcome opportunities for research training for African geoscience students. Nontechnical outreach programs for local communities have proven successful for many drilling projects in the past (including at Lake Malawi in East Africa), and there was great enthusiasm at the meeting for developing a vigorous program along these lines for many different types of audiences. Because human evolution is a high profile target for scientific endeavors, many opportunities also exist for major museums to become involved in disseminating the results of HSPDP worldwide.

HSPDP opens up a new direction for scientific drilling. Although the focus of the immediate project is East Africa, the concept of developing synergies between the Earth science and paleoanthropology communities can (and almost certainly will) be applied worldwide, wherever the questions of relationships between human evolution and Earth system history arise. Future phases in such research might also involve collaborative ICDP/IODP efforts to collect new marine cores in critical locations and/or marine/terrestrial coring transects, as well as new drilling efforts on the extant and ancient deep rift lakes. "Drilling for human origins" promises to become an exciting new research direction in the years ahead. 


\section{Acknowledgements}

We thank the U.S. National Science Foundation (Grant $\# 0725553)$ and the International Continental Scientific Drilling Program for support of the site survey (NSF) and drilling workshop (ICDP and NSF) work discussed in this report. We also thank the governments of Kenya (Ministry of Science and Technology) and Ethiopia (ARCCH) for providing research permits and support for this project.

\section{References}

Alemseged, Z., Wynn, J.G., Kimbel, W.H., Reed, D., Geraads, D., and Bobe, R., 2005. First hominin from the Basal Member of the Hadar Formation, Dikika, Ethiopia and its geological context. J. Hum. Evol., 49:499-514, doi:10.1016/j.jhevol. 2005.06.001.

Behrensmeyer, A.K., 2008. Paleoenvironmental context of the Pliocene A.L. 333 "First Family" hominin locality, Hadar Formation, Ethiopia. In: Quade, J., and Wynn, J.G. (Eds.), The Geological Context of Human Evolution in the Horn of Africa. Geological Society of America Special Paper, 446: 203-214.

Behrensmeyer, A.K., Potts, R., Deino, A., and Ditchfield, P., 2002. Olorgesailie, Kenya: a million years in the life of a rift basin. In: Renaut, R.W., and Ashley, G.M. (Eds.), Sedimentation in Continental Rifts, SEPM Spec. Publ., 73:97-106.

Campisano, C.J., and Feibel, C.S., 2007. Connecting local environmental sequences to global climate patterns: evidence from the hominin-bearing Hadar Formation, Ethiopia. J. Hum. Evol., 53:515-527, doi:10.1016/j.jhevol.2007.05.015.

Campisano, C.J., and Feibel, C.S., 2008. Depositional environments and stratigraphic summary of the Hadar Formation at Hadar, Afar Depression, Ethiopia. In: Quade, J., and Wynn, J.G., eds. The Geology of Early Humans in the Horn of Africa, Boulder, Colo. (Geological Society of America), 179-201.

Cohen, A.S., Ashley, G.M., Potts, R., Behrensmeyer, A.K., Feibel, C., and Quade, J., 2006. Paleoclimate and Human Evolution Workshop. Eos Trans. Am. Geophys. Union, 87(16):161, doi:10.1029/2006EO160008.

Cohen, A.S., Stone, J.R., Beuning, K.R., Park, L.E., Reinthal, P.N., Dettman, D., Scholz, C.A., Johnson, T.C., King, J.W., Talbot, M.R., Brown, E.T., and Ivory, S.J., 2007. Ecological consequences of early Late-Pleistocene megadroughts in tropical Africa. Proc. Nat. Acad. Sci., 104:16422-16427, doi:10.1073/pnas.0703873104.

Cowling, S.A., Cox, P.M., Jones, C.D., Maslin, M.A., Peros, M., and Spall, S.A., 2008. Simulated glacial and interglacial vegetation across Africa: implications for species phylogenies and trans-African migration of plants and animals. Global Change Biol., 14:827-840, doi:10.1111/j.1365-2486. 2007.01524.x.

Damnati, B., and Taieb, M., 1995. Solar and ENSO signatures in laminated deposits from Lake Magadi (Kenya) during the Pleistocene/Holocene transition. J. Afr. Earth Sci., 21:373-382, doi:10.1016/0899-5362(95)00094-A.

Deino, A.L., Kingston, J.D., Glen, J.M., Edgar, R.K., and Hill, A., 2006. Precessional forcing of lacustrine sedimentation in the late Cenozoic Chemeron Basin, Central Kenya Rift. Earth
Planet. Sci. Lett., 247:41-60, doi:10.1016/j.epsl.2006.04.009. deMenocal, P.B., 1995. Plio-Pleistocene African climate. Science, 270:53-59, doi:10.1126/science.270.5233.53.

deMenocal, P.B., 2004. African climate change and faunal evolution during the Plio-Pleistocene. Earth Planet. Sci. Lett., 220:3-24, doi:10.1016/S0012-821X(04)00003-2.

Dupont-Nivet, G., Sier, M., Campisano, C.J., Arrowsmith, R., DiMaggio, E., Reed, K., Lockwood, C., Franke, C., and Häusing, S., 2008. Magnetostratigraphy of the homininbearing Hadar Formation (Ledi-Geraru, Ethiopia), and regional evidence for environmental change ca. 3.2 Ma. In: Quade, J., and Wynn, J.G. (Eds.), The Geology of Early Humans in the Horn of Africa. Boulder, Colo. (Geological Society of America), 67-86.

Eugster, H.P., 1980. Lake Magadi, Kenya and its precursors. In: Nissenbaum, A., (Ed.), Hypersaline Brines and Evaporites. Amsterdam (Elsevier), 195-232.

Feakins, S.J., deMenocal, P.B., and Eglinton, T.I., 2005. Biomarker records of late Neogene changes in northeast African vegetation. Geology, 33:977-980, doi:10.1130/G21814.1.

Feibel, C.S., Brown, F.H., and McDougall, I., 1989. Stratigraphic context of fossil hominids from the Omo Group deposits: Northern Turkana Basin, Kenya and Ethiopia. Am. J. Phys. Anthro., 78:595-622, doi:10.1002/ajpa.1330780412.

Harris, J.M., Brown, F.H., and Leakey, M. G., 1988. Geology and paleontology of Plio-Pleistocene localities west of Lake Turkana, Kenya. Contributions in Science, 399:1-128.

Isaac, B., and Isaac, G.L., 1977. Olorgesailie: Archeological Studies of a Middle Pleistocene Lake Basin in Kenya. Chicago (University of Chicago Press), 272pp.

Johanson, D.C., and White, T.D., 1979. A systematic assessment of early African hominids. Science, 203:321-330, doi:10.1126/ science. 104384.

Johanson, D.C., Taieb, M., and Coppens, Y., 1982. Pliocene hominids from the Hadar Formation, Ethiopia (1973-1977): stratigraphic, chronological and paleoenvironmental contexts, with notes on hominid morphology and systematics. Am. J. Phys. Anthro., 57:373-402, doi:10.1002/ajpa. 1330570402.

Kingston, J.D., Deino, A., Hill, A., and Edgar, R., 2007. Astronomically forced climate change in the Kenyan Rift Valley 2.7-2.55 Ma: implications for the evolution of early hominin ecosystems. J. Hum.Evol., 53:487-503, doi:10.1016/j.jhevol.2006.12.007.

Lepre, C.J., Quinn, R.L., Joordens, J.C.A., Swisher, C.C., and Feibel, C.S., 2007. Plio-Pleistocene facies environments from the KBS Member, Koobi Fora Formation: implications for climate controls on the development of lake-margin hominin habitats in the northeast Turkana Basin (northwest Kenya). J. Hum. Evol., 53:504-514, doi:10.1016/j.jhevol.2007.01.015.

Lewin, R., 1981. Lake bottoms linked with human origins. Science, 211:564-566, doi:10.1126/science.211.4482.564.

Owen, R.B., Potts, R., Behrensmeyer, A.K., and Ditchfield, P., 2008. Diatomaceous sediments and environmental change in the Pleistocene Olorgesailie Formation, southern Kenya Rift Valley. Palaeogeogr. Palaeoclimatol. Palaeoecol., 269:17-37, doi:10.1016/j.palaeo.2008.06.021.

Potts R., 1996. Evolution and climatic variability. Science, 273:922-923, doi:10.1126/science.273.5277.922.

Potts, R., and Deino, A., 1995. Mid-Pleistocene change in large mam- 
mal faunas of the southern Kenya rift. Quat. Res., 43:106-113, doi:10.1006/qres.1995.1010.

Potts, R., Behrensmeyer, A.K., Deino, A., Ditchfield, P., and Clark, J., 2004. Small mid-Pleistocene hominin associated with East African Acheulean technology. Science, 305:75-78, doi:10.1126/science.1097661.

Roche, H., Brugal, J.-P., Delagnes, A., Feibel, C., Harmand, S., Kibunjia, M., Prat, S., and Texier, P.-J., 2004. Plio-Pleistocene archaeological sites in the Nachukui Formation, West Turkana, Kenya: synthetic results 1997-2001. Comptes Rendus Palevol, 2:663-673.

Scholz, C.A., Cohen, A.S., Johnson, T.C., and King, J.W., 2006. The 2005 Lake Malawi Scientific Drilling Project. Sci. Drill., 2:17-19, doi:10.2204/iodp.sd.1.04.2006.

Sepulchre, P., Ramstein, G., Fluteau, R., Schuster, M., Tiercelin, J.J., and Brunet, M., 2006. Tectonic uplift and Eastern Africa aridification. Science, 313:1419-1423, doi:10.1126/ science.1129158.

Semaw, S., Renne, P., Harris, J.W.K., Feibel, C.S., Bernor, R.L., Fesseha, N., and Mowbray, K., 1997. 2.5-million-year-old stone tools from Gona, Ethiopia. Nature, 385:333-336, doi:10.1038/385333a0.

Suwa, G., Asfaw, B., Haile-Selassie, Y., White, T., Katoh, S., Woldegabriel, G., Hart, W.K., Nakaya, H., and Beyene, Y., 2007. Early Pleistocene Homo erectus fossils from Konso, southern Ethiopia. Anthro.Sci., 115:133-151, doi:10.1537/ ase.061203.

Taieb, M., Barker, P., Bonnefille, R., Damnati, B., Gasse, F., Goetz, C., Hillaire, C., Icole, M., Masault, M., Roberts, N., Vincens, A., and Willamson, D., 1991. Histoire paléohydrologique du lac Magadi (Kenya) au Pleistocène superieur. C. R. Acad. Sci., Sér. 2, 313:339-346.

Trauth, M.H., Larrasoaña, J.C., and Mudelsee, M., 2009. Trends, rhythms and events in Plio-Pleistocene African climate. Quat. Sci. Rev., 28:399-411, doi:10.1016/j.quascirev. 2008.11.003.

Vrba, E.S., 1988. Late Pliocene climatic events and hominid evolution. In: Grine, F.E. (Ed.), Evolutionary History of the "Robust" Australopithecines. New York (Aldine de Gruyter), 405-426.

Wynn, J.G., Roman, D.C., Alemseged, Z., Reed, D., Geraads, D., and Munro, S., 2008. Stratigraphy, depositional environments, and basin structure of the Hadar and Busidima Formations at Dikika, Ethiopia. In: Quade, J., and Wynn, J.G., (Eds.), The Geological Context of Human Evolution in the Horn of Africa. Geological Society of America Special Paper, 446:87-118.

\section{Authors}

Andrew Cohen, Department of Geosciences, University of Arizona, Tucson, Ariz., U.S.A., e-mail: cohen@email.arizona. edu.

Ramon Arrowsmith, School of Earth and Space Exploration, Arizona State University, Tempe, Ariz., U.S.A., e-mail: ramon.arrowsmith@asu.edu.

Anna K. Behrensmeyer, Department of Paleobiology, National Museum of Natural History, Washington, DC, U.S.A., e-mail: behrensa@si.edu.
Christopher Campisano, Institute of Human Origins, Arizona State University, Tempe, Ariz., U.S.A., e-mail: campisano@asu.edu.

Craig Feibel, Departments of Geological Sciences and Anthropology, Rutgers University, New Brunswick, N.J., U.S.A., e-mail: feibel@rci.rutgers.edu.

Shimeles Fisseha, Department of Earth Sciences, Addis Ababa University, Addis Ababa,Ethiopia, e-mail:wmike199@ gmail.com.

Roy Johnson, Department of Geosciences, University of Arizona, Tucson, Ariz., U.S.A., e-mail:johnson6@email.arizona.edu.

Zelalem Kubsa Bedaso, Department of Geology, University of South Florida, Tampa, Fla., U.S.A., e-mail:zelex24@yahoo. com.

Charles Lockwood (†deceased), Department of Anthropology, University of Wittwatersrand, Johannesburg, South Africa.

Emma Mbua, Department of Paleontology, National Museums of Kenya, Nairobi, Kenya, e-mail:enmbua@yahoo. com.

Daniel Olago, Department of Geology, University of Nairobi, Nairobi, Kenya, e-mail: dolago@uonbi.ac.ke.

Richard Potts, Human Origins Program, National Museum of Natural History, Washington, DC, U.S.A., e-mail:pottsr@ si.edu.

Kaye Reed, Institute of Human Origins, Arizona State University, Tempe, Ariz., U.S.A., e-mail:kreed.iho@asu.edu.

Robin Renaut, Department of Geological Sciences, University of Saskatchewan, Saskatoon, Saskatchewan, Canada, e-mail:robin.renaut@usask.ca.

Jean-Jacques Tiercelin, CNRS, Université de Rennes, Rennes, France, e-mail:jean-jacques.tiercelin@univ-rennes1. fr.

Mohammed Umer, Department of Earth Sciences, Addis Ababa University, Addis Ababa, Ethiopia, e-mail:moha umero@yahoo.com.

\section{Web Links}

http://magadi.icdp-online.org http://malawidrilling.syr.edu/photos/Outreach\%20 Program/index.html

\section{Photo Credits}

Fig. 3: Photo by R. Johnson. 